\title{
XXXIX. Short account of the rocks in the Neighbourhood of St. John's, Newfoundland
}

\section{Mr. John Baird}

To cite this article: Mr. John Baird (1822) XXXIX. Short account of the rocks in the Neighbourhood of St. John's, Newfoundland, Philosophical Magazine Series 1, 60:293, 206-210, DOI: $10.1080 / 14786442208652823$

To link to this article: http://dx.doi.org/10.1080/14786442208652823

里 Published online: 29 Jul 2009.

Submit your article to this journal $₫$

Џll Article views: 3

Q View related articles $₫$ 
in the higher regions of the atmosphere, where it is equally spread, and where it must naturally be compelled towards the poles by the perpetual current of the air from the equator towards them. Such an accumulation not only might furnish the reason of the frequency of that decidedly electrical phænomenon which is called aurora borealis on the North, and which is not less rare towards the Southern Pole, but might perhaps render a just reason for the great part which the atmospherical water might take in the formation of the inexhaustible ices of the polar regions.

XXXVIII. On Lithographic Printing.

To the Editors of the Philosophical Magazine and Journal.

Gentlemen,- Havrng found considerable inconvenience arise from the use of grease on the surface of the stretched leather in the tympan frame, over which the scraper passes, -on account of the dirt it creates, the injury it occasions to the leather, and the waste of paper, -I have tried various substitutes.

The most successful experiment I have yet made, has been with Castile soap rubbed over the leather with a little water. It very speedily produces, by the action of the scraper passing over it, a glossy surface; and I feel confident that the labour in working the press is even less than when grease is employed. This, in addition to the other advantages it possesses, viz. cleanliness and œconomy, strongly recommend its use to those employed in lithographic printing-particularly those who practise it as an amusement.

I am, gentlemen, your obedient servant,

The Lithographic Press,

8, Pickett-street, Strand, Sept. 23, 1822.

Charles M. Willich.

XXXIX. Short Account of the Rocks in the Neighbourhood of St. John's, Nerefoundland. By Mr. JoHn Baind*.

$\mathbf{I}_{\mathrm{N}}$ approaching the fishing grounds on the coast of America, the soundings were from sixty to thirty fathoms; over the great Bank of Newfoundland, generally about thirty-five. The lead brought up a fine sand, and frequently small pieces of a rough flint, together with particles of a green smooth mineral, in the form of coarse green sand. It is certainly a singular fact, that so large a portion of shallow water should exist so

* From the Memoirs of the Wernerian Natural History Society for 1821-2… Vol. iv. Part I. 
far out at sea, the sea deepening so rapidly beyond the Bank. Is it not probable that a large tract of dry land had formerly existed where the Bank is now found? The rocks which formed this land may have been composed of very soft materials, and the occurrence of flint and green sand over the bank seems to indicate that the greater part of the original rocks had been of the chalk and green sand formations. A country composed of these rocks, which are of the latest formation, must have been very low, and in consequence much exposed to the action of the sea. By degrees the whole may have been inundated and entirely swept away, leaving the harder debris, the flint and green sand, to form the gravel at the bottom.

The coast round St. John's is bleak, bare, and rocky, and almost every where precipitous. On both sides of St. John's harbour, perpendicular cliffs of trap-tuff rise to the height of three or four hundred feet. The interior of the country is hilly, but does not rise to a great elevation, few of the hills being more than five or six hundred feet above the level of the sea. They are generally round-backed, and frequently wooded to the top. The whole uninhabited part of the country is one immense forest, consisting chiefly of fir and birch. No extensive valleys or plains occur, but hill succeeds hill in almost unvarying succession. The physiognomy of the country is an elegant outline of hill and dale: the scenery, however, wants variety. Lakes are numerous over the whole island, as far as it is known, and many of them, near the coast, are large and beautiful. They occur even on the tops of the hills, and are said to be often of great depth. 'The soil is in general light. Oats and barley thrive; and potatoes, turnips, and other kitchen vegetables, grow fully as well as in England. Summer weather, in Newfoundland, is short, but warm, and very favourable to vegetation. The winter is uncommonly severe, the spring and autumn very changeable. There is good pasture for cattle in ground that is cleared.

The passage into St. John's harbour, which in shape very much resembles a man's foot, is by a narrow entrance, called The Narrows, which extends nearly east and west about half a mile. Both sides of this entrance are high, abrupt, and rocky. The rocks are the same on each side, being continued across from the one to the other. I think there is little doubt that the opposite sides of the Narrows had once been joined. A rapid river runs into the harbour. The harbour itself, previously to the formation of the Narrows, may have been a lake. The river appears to have been once much larger. By the action of the sea without, and of the river and lake within, the 
rent or chasm by which the river formerly emptied itself into the sea, may have been gradually enlarged, till it has attained its present size. The average width may be two or three hundred yards. Quidi Vidi (pronounced Kitty-vitty) river and lake may one day present an entrance and harbour similar to those of St. John's.

The mineralogy of the country round St. John's is very simple. The first rock, on entering the Narrows, is trap-tuff. This rock is distinctly stratified, each stratum generally measuring two or three feet in thickness. The strata lie NE. and SW., or rather NE. by N. and SW. by S. The dip is to the NW., at an angle of from $70^{\circ}$ to $80^{\circ}$. The basis of this rock consists chiefly of distinct grains of quartz, felspar, and a red claystone. The imbedded minerals or pebbles are, for the most part, of the same substances; felspar, common and compact, the latter with small imbedded grains of quartz; quartz, often of a slaty or fibrous structure; jasper, red claystone, bloodstone, hornstone, \& c. These imbedded minerals, at the foot of the hill or cliff (particularly the quartz and felspar), are generally from an inch to three inches in diameter, and gradually decrease as we ascend; at the top of the hill, they rarely exceed the fourth part of an inch in diameter. Does not this fact countenance the mechanical deposition of the trap-tuff? This rock appears much harder than the common varieties of the trap-tuff which I have seen.

It is this rock which forms those precipitous cliffs on either side of the mouth of the Narrows. 'The opposite sides of the Narrows rise very rapidly from the sea to a considerable height. The highest part of the trap-tuff formation is about 300 feet above the sea; its thickness about 500 yards. The trap-tuff' passes very gradually, and most beautifully, into the next rock, which is amygdaloid. In this passage of the one rock into the other, the stratified structure is still retained, one stripe or narrow stratum being distinctly marked trap-tuff, the next anygdaloid; the stripes of the former being broadest at first, gradually becoming narrower and less defined, till the anygdaloidal rock entirely prevails.

The strata of the amygdaloid also run in the direction of NE. by N. and SW. by S., and dip likewise to the NW. at an angle of about $65^{\circ}$. The basis of this rock, like that of the trap-tuff, consists of minute grains of quartz, felspar, and claystone. The imbedded portions are invariably of a red, smooth, hard claystone: they seldom have the amygdaloidal form, but are square, or rhomboidal, or in longish slates. The greater part of the amygdaloidal rock is entirely destitute of these 
portions, while, on the other hand, more than one-half of some of the strata is composed of them. The anyggdaloid is frequently distinctly stratified, each stratum being a few feet thick.

The trap-tuffi and amygdaloid are both of a reddish coloux; the latter, however, sometimes occurs of a grey colour. 'The greatest height of the amygdaloid formation is 500 feet * ; its thickness is about three or four hundred yards, extending from the top of Signal Hill to the foot of the Crow's Nest.

Resting upon the amygdaloid is found the greenstone, lower in height than the amygdaloid, but higher than the trap-tuff: This rock extends from the foot of the Crow's Nest (it being. of greenstone) to the foot of the Signal Hill, or to the town of St. John's, a thickness of six or seven huncired yards. The Crow's Nest, on which is built a small fort, is four hundred feet above the level of the sea. The principal constituent part of this rock is apparently felspar. Its most common colour is green, though sometimes gray and red; it is stratified, and sometimes possesses a beautiful slaty structure. The strata of the greenstone also run NE. and \$W.; their dip is to the NW., at a much smaller angle than the preceding rock, the inclination not exceeding $50^{\circ}$.

Resting upon the greenstone we find the next rock claystone, the strata of which have the same direction and dip as the others, the angle of inclination, however, not being above $35^{\circ}$ or $4.0^{\circ}$. The claystone formation extends two miles in thickness beyond the greenstone, occasionally alternating with strata of compact felspar, each stratum measuring from half a foot to a foot in thickness. The claystone being much softer than the rocks before described, the country where it prevails is also much lower. The town of St. John's is built upon the claystone. In colour, it is most frequently gray, often alsa brown, dark-brown, red, whitish, and of other colours. It is often beautifully striped. It is fine-grained, smooth, and often conchoidal in the fracture. The strata of this rock are occasionally columnar, which is also sometimes the case with the greenstone; and the columns are composed of round concentric balls.

The next rock, whose direction, dip, and inclination are the same as those of the claystone, is compact felspar. This rock first alternates with the claystone, and then prevails alone for above a mile. Being harder than the claystone, the country composed of it is higher. Its colour is also various, light and dark gray, greenish-gray, green, blue, \&c. It is translucent, or slightly translucent, on the edges, while the claystone is

* This is the height of Signal Hill, the highest part of the formation.
Vol. 60. No. 293. Sept. 1822.
$\mathrm{D} d$
perfectly 
perfectly opaque. The compact felspar has a splintery conchoidal fracture; the fracture of the claystone, on the other hand, is even, and always smooth. The compact felspar is more or less fine in the grain, and the splinters more or less large. The strata of the compact felspar, like those of the greenstone and claystone, are also at times columnar, the columns being composed of small round concentric balls, and very brittle. These balls are at times partially composed of hornstone. This mineral occurs also in the compact felspar, in thin beds, in veins, and in masses; its colour is green, its fracture smooth, conchoidal, it is slightly translucent on the edges, and is as hard as quartz.

Claystone again succeeds the compact felspar, and the latter is again succeeded by the former, thus alternating for about eight or ten miles across the peninsula. The claystone always possesses a slaty structure, and soon decays. The soil over the greenstone and amygdaloid is rich and good, while over the claystone and compact felspar it is light and poor.

XL. Reply to Captain Forman's Theory of the Tides. By Mr. Henky Russeli.

\section{To the Editors of the Philosophical Magazine and Journal.}

Gentlemen, - $\mathbf{T H E}_{\mathrm{E}}$ expansibility of water being a well attested fact, Captain Forman's theory will no doubt meet with due attention; but I am persuaded that very few will be delighted with his method of reasoning.

With regard to his question, "Do the waters at the time of their rising press downwards, or do they not?" I answer, 'They press downwards; but with as much less power as is equal to the attractive power of the moon.

To the next question, "How are we to account for their rising, except by supposing that they are pressed upwards by the expansion of the particles below?" I answer, By the superior gravity of those waters which constitute the ebb.

I do not deny an expansion and contraction of the waters occasioned by the arrival and departure of the moon; but the circumstance of the highest tides being invariably accompanied by the lowest ebbs, is alone sufficient to convince any impartial inquirer, that the ebb and flow of the waters are produced by changes of place, and not by rarefaction and condensation alone.

The satisfaction which Mr. Forman seems to derive from a handful of water is by no means enviable. He speaks of 